\title{
Screening of hearing ability and hearing threshold among traffic police
}

\author{
Nisha Ghimire', Sanjeev Kumar Thakur², Abishesa Kumar Jha ${ }^{3}$, Renu Yadav ${ }^{4}$, \\ Soumitra Mukhopadhyay ${ }^{5}$ \\ ${ }_{1,4}^{1,4}$ Assistant Professor, ${ }^{5}$ Professor and Head, Department of Physiology, Nobel Medical College, Biratnagar, Nepal, \\ ${ }^{2}$ Lecturer, Department of ENT, Nobel Medical College, Biratnagar, Nepal, ${ }^{3}$ Audiologist, Department of ENT, Nobel \\ Medical College, Biratnagar, Nepal
}

Background: Traffic police are continually exposed to loud noise. The pure tone audiometric screening for hearing test has not been done in Biratnagar Nepal. The traffic police personnel in Biratnagar might have noise induced hearing loss. Aims and Objective: To Screen the hearing loss prevalence among traffic policemen of Biratnagar and to find out the hearing threshold among traffic police with normal hearing ability. Materials and Methods: The study was conducted among 36 traffic police personnel. The $25 \mathrm{~dB}$ sound was administered with conventional audiometer and headphone in different frequency tones $(1 \mathrm{kHz}, 2 \mathrm{kHz}$, $3 \mathrm{kHz}, 4 \mathrm{kHz}$ and $8 \mathrm{kHz}$ ) for screening hearing loss in left and right ears. The threshold for hearing among normal hearing traffic personnel was compared with controls in all the frequencies. Result: Among 36 traffic police, $17(47.2 \%)$ had hearing loss. Maximum $(n=8)$ hearing loss was seen in $4 \mathrm{kHz}(4$ - unilateral and 4 - bilateral) followed by $3 \mathrm{kHz}(\mathrm{n}=4$, 3 unilateral and 1 bilateral) and mixed $3 \mathrm{kHz}$ and $4 \mathrm{kHz}$ frequencies. The percentage of hearing loss in $2 \mathrm{kHz}, 3 \mathrm{kHz}$ and $4 \mathrm{kHz}$ frequencies was more in left ear compared to right. The threshold for hearing was higher in traffic police compared to controls. In the left ear, it was only in $4 \mathrm{kHz}\{(25.91 \pm 6.64 \mathrm{Vs} 20.45 \pm 4.15,(\mathrm{p}=.034)\}$ whereas in right ear, the threshold was higher in $3 \mathrm{kHz}\{20.45 \pm 5.22 \mathrm{Vs} 15.91 \pm 4.90,(p=0.04)\}$, $4 \mathrm{kHz}\{25.45 \pm 12.54 \mathrm{Vs} 16.82 \pm 5.60,(p=0.05)\}$ and $8000 \mathrm{kHz}\{18.64 \pm 17.62 \mathrm{Vs}$ $6.36 \pm 3.23,(p=0.04)$. Conclusion: The hearing loss was present in $47.2 \%$ of traffic policemen predominantly in $4 \mathrm{kHz}$. The threshold for hearing was also higher among traffic police compared to controls.

Key words: Hearing loss; Hearing threshold; Traffic police; Biratnagar

\section{INTRODUCTION}

Traffic police are exposed continuously to loud noise. WHO estimates that globally $16 \%$ of individuals have a moderate to greater degree of hearing loss due to occupational noise exposure. ${ }^{1}$ Audiometric screening is recommended for the person exposed to occupational noise. If any hearing loss is found, they should be referred for proper audiological test as it is preventable if the protective measures are used. ${ }^{2}$ According to the studies conducted in different parts of Nepal, the noise level was above recommended value. ${ }^{3,4} \mathrm{~A}$ study done in Kathmandu valley amongthe traffic police showed that traffic police are in constant risk of noise induced hearing loss (NIHL) and screening for hearing loss is recommended for people exposed to noise. ${ }^{4}$ The study conducted to assess the hearing quality of traffic-policemen in Dharan-Biratnagar corridor suggested that the traffic police showed normal hearing on the questionnaire based test however the audiometric test was recommended. ${ }^{5}$ So it was worth conducting the study to screen the traffic- police personnel of Biratnagar with pure tone audiometer for hearing quality and also to find out the threshold for hearing among traffic police. This study will help to assess the hearing ability of traffic policemen in Biratnagar which could be used as reference for study in larger population. 


\section{MATERIALS AND METHODS}

This cross-sectional study was conducted among traffic personnel in Biratnagar traffic office in Traffic-chowk. The study was conducted from September 2017 to October 2018. Ethical clearance was taken from Institutional Review board Nobel Medical College. The permission was also taken from traffic office for the test. A total of 44 traffic personnel were presently working there. Name, age and duration of job were enquired. Self prepared questionnaire was asked to each subject to evaluate the overall health status. Questionnaire also included the duration of job, use of protective measures such as mask and ear plugs, hobbies with possible excessive noise exposure such as listening to loud music, recent history of ear infection, and history of head or neck injury. History of exposure to chemicals and medications and family history of hearing loss were also asked.

\section{Exclusion criteria}

Subjects with diabetes mellitus, hypertension, ear drum perforation, acute or chronic suppurative otitis media, wax and suffering from ear diseases were excluded from the study. After detailed physical examination, ear examination was done. Three subjects were found to have chronic suppurative otitis media, one had hypertension and two subjects including female were office staffs who were not directly exposed to noise, two could not manage to come because of their busy schedule. So the study was conducted among total of 36 traffic police, after written informed consent. Conventional audiometer with headphone was used for screening and it was performed in quiet room. The sound level was measured with audiometer. Wearing the audiometer earphones, the screening frequency pure tones $(1000 \mathrm{~Hz}, 2000 \mathrm{~Hz}$, and $4000 \mathrm{~Hz})$ was heard at a level of $10 \mathrm{~dB}$. (Guidelines for hearing screening in the School Setting $)^{6}$ the test was done during morning hour before the duty hour and those on duty were called later to avoid the stress of night shift. $25 \mathrm{~dB}$ sounds was administered for screening the hearing loss. ${ }^{7}$ Those who could not hear $25 \mathrm{~dB}$ sound were referred to ENT OPD for further treatment. Out of 36 traffic policemen, 19 had normal hearing. They were requested to come to ENT OPD to find out the hearing threshold out of which only eleven could come for the test. Age, sex and Body mass index matched laboratory technicians who were working in the same area were taken as controls. BMI matched controls were chosen as a increased prevalence of hearing loss has been found in underweight and obese person. ${ }^{8}$ Convenient sampling technique was done. The controls were screened and those with normal hearing within $25 \mathrm{~dB}$ were selected. The threshold for hearing at different hertz was taken with audiometer in both ears. Each ear was evaluated separately. When the subject heard the tone, the tone was reduced by $10 \mathrm{~dB}$ till subject stopped hearing. Once this stage was reached, the tone was raised by $5 \mathrm{~dB}$. If the subject heard this tone, the sound was again decreased by $10 \mathrm{~dB}$. If he did not hear, the tone was again raised by $5 \mathrm{~dB}$. In this way the exact hearing threshold was obtained. ${ }^{7}$

\section{Statistical analysis}

All the data were entered in excel sheet and analysis was done. The frequency of hearing loss in right and left ears were calculated. The comparison of anthropometric variables and threshold of hearing between controls and normal hearing traffic police was done with independent $\mathrm{t}$-test. The comparison of hearing between left and right ears in both traffic police and controls was also done with paired t- test. Data were expressed as frequency and percentage. The threshold of hearing was expressed as Mean \pm SD.

\section{RESULTS}

The characteristics of traffic policemen is tabulated in Table 1 Out of 36 traffic police examined, 17(47.2\%) had hearing loss (Table 2). Out of these17 traffic policemen, eight ( $\mathrm{n}=8)$ of them had hearing loss in $4 \mathrm{kHz}$ (4 - unilateral and 4 - bilateral), 4 of them had loss in $3 \mathrm{kHz}(\mathrm{n}=4,3$ unilateral and 1 bilateral) and remaining 5 of them had hearing loss in mixed $2 \mathrm{kHz}, 3 \mathrm{kHzand} 4 \mathrm{kHz}$ frequencies (Table 3). Out of both right and left 36 ears (Table 4), when PTA was done in $4000 \mathrm{kHz}, 15$ (41.7\%)

\begin{tabular}{lcc}
$\begin{array}{l}\text { Table 1: Distribution of characteristics of traffic } \\
\text { policemen }(\mathbf{n = 3 6 )}\end{array}$ & Number & Percentage (\%) \\
\hline Characteristics & & \\
\hline Tinnitus & 8 & 22.2 \\
$\quad$ Yes & 28 & 78.2 \\
$\quad$ No & & \\
Earfullness & 8 & 22.2 \\
$\quad$ Yes & 28 & 78.2 \\
$\quad$ No & & \\
Protection & 2 & 5.6 \\
$\quad$ Yes & 34 & 94.5 \\
$\quad$ No & & \\
Duration of service & 2 & 5.55 \\
$\quad<5$ & 13 & 36.11 \\
5-9 & 13 & 36.11 \\
10-14 & 8 & 22.22 \\
$\quad>14$ & & \\
Working hours in a day & 24 & 66.66 \\
$8-10$ hrs & 12 & 33.33 \\
11-16 hrs & & \\
\hline
\end{tabular}

\begin{tabular}{|c|c|c|}
\hline $\begin{array}{l}\text { Number and \% } \\
\text { hearing at } 25 \mathrm{~dB}\end{array}$ & $\begin{array}{c}\text { Number and } \% \text { not } \\
\text { hearing at } 25 \mathrm{~dB}\end{array}$ & $\begin{array}{l}\text { Total number of } \\
\text { subjects }(n)=36\end{array}$ \\
\hline $19(52.8)$ & $17(47.2)$ & 36 \\
\hline
\end{tabular}


Table 3: Frequency of unilateral and bilateral hearing loss among traffic policemen

\begin{tabular}{lccccccc}
$\begin{array}{l}\text { Unilateral } \\
\mathbf{4 k H z} \text { loss }\end{array}$ & $\begin{array}{c}\text { bilateral } \\
\mathbf{4 k H z} \text { loss }\end{array}$ & $\begin{array}{c}\text { Unilateral } \\
\mathbf{3 k H z} \text { loss }\end{array}$ & $\begin{array}{c}\text { Bilateral } \\
\mathbf{3 k H z} \text { loss }\end{array}$ & $\begin{array}{c}\text { Unilateral 2kHz, } \\
\mathbf{3 k H z}, \mathbf{4 k H z} \text { loss }\end{array}$ & $\begin{array}{c}\text { Mixed } \\
\text { frequencies loss }\end{array}$ & Normal & Total (n) \\
\hline $4(11.11) \%$ & $4(11.11 \%)$ & $3(8.33) \%$ & $1(2.77) \%$ & $1(2.77) \%$ & $4(11.11) \%$ & $19(52.77) \%$ & 36 \\
\hline nnnumber of subjects & & & & & &
\end{tabular}

\begin{tabular}{|c|c|c|c|c|}
\hline \multirow{3}{*}{$\begin{array}{l}\text { Frequency } \\
\mathrm{Hz}\end{array}$} & \multicolumn{4}{|c|}{ Numberand percentage (\%) of subjects $n=36$} \\
\hline & \multicolumn{2}{|c|}{ Left } & \multicolumn{2}{|c|}{ Right } \\
\hline & $\begin{array}{l}\text { Heard } \\
25 \mathrm{db}\end{array}$ & $\begin{array}{l}\text { Not heard } \\
25 \mathrm{db}\end{array}$ & $\begin{array}{l}\text { Heard } \\
25 \mathrm{db}\end{array}$ & $\begin{array}{l}\text { Not heard } \\
25 \mathrm{db}\end{array}$ \\
\hline 1000 & $36(100)$ & 0 & $36(100)$ & 0 \\
\hline 2000 & $34(94.4)$ & $2(5.6)$ & $36(100)$ & 0 \\
\hline 3000 & 30 (83.3) & $6(16.7)$ & 32 (88.9) & $4(11.1)$ \\
\hline 4000 & $21(58.3)$ & $15(41.7)$ & $25(69.4)$ & $11(30.6)$ \\
\hline 8000 & $36(100)$ & $0(0)$ & $36(100)$ & $0(0)$ \\
\hline
\end{tabular}

Table 5: Comparison of anthropometric variables between traffic police and controls

\begin{tabular}{lccc}
\hline $\begin{array}{l}\text { Anthropometric } \\
\text { Parameters }\end{array}$ & $\begin{array}{c}\text { Traffic } \\
\text { police } \mathbf{n}=\mathbf{1 1}\end{array}$ & $\begin{array}{c}\text { Controls } \\
\mathbf{n}=\mathbf{1 1}\end{array}$ & p-value \\
\hline Age & $29.27 \pm 4.71$ & $28.91 \pm 4.94$ & 0.86 \\
SBP & $114.55 \pm 7.90$ & $107.45 \pm 6.69$ & 0.035 \\
DBP & $74.55 \pm 4.29$ & $72.0 \pm 6.38$ & 0.288 \\
BMI & $23.16 \pm 1.43$ & $22.69 \pm 0.93$ & 0.381 \\
\hline
\end{tabular}

SBP-Systolic blood pressure, DBP-Diastolic blood pressure, BMI- Body mass index

had hearing loss in left ear and $11(30.6 \%)$ had loss in right ear. In $3000 \mathrm{kHz}, 6(16.7 \%)$ had hearing loss in left ear and $4(11.1 \%)$ had loss in right ear. In $2000 \mathrm{kHz}, 2(5.6 \%)$ had hearing loss in left ear where no hearing loss was seen in right ear. No hearing loss was seen in other frequencies. The anthropometric variables between traffic police and controls were compared. (Table 5) No significant difference was appreciated between two groups. When the threshold of hearing was compared between traffic police and controls, (Table 6) the traffic police showed higher threshold for hearing in $4000 \mathrm{kHz}$ in left ears $\{(25.91 \pm 6.64$ vs.20.45 $\pm 4.15,(p=.034)\}$ whereas no significance was seen among other frequencies. When the same comparison was done in right ear, the significance was seen in $3000 \mathrm{kHz}$ $\{20.45 \pm 5.22$ Vs 15.91 $\pm 4.90,(\mathrm{p}=0.04)\}, 4000 \mathrm{kHz}$ $\{25.45 \pm 12.54 \mathrm{Vs} 16.82 \pm 5.60,(\mathrm{p}=0.05)\}$ and $8000 \mathrm{kHz}$ $\{18.64 \pm 17.62 \mathrm{Vs} 6.36 \pm 3.23,(\mathrm{p}=0.04)\}$.The right ears and left ears of both traffic police and controls were compared (Table 7). The threshold of hearing was more in left ears in both groups. However, among the traffic policemen, the threshold of hearing was higher in $250 \mathrm{~Hz}, 500 \mathrm{~Hz}$ and $2000 \mathrm{~Hz}$ whereas among controls also the threshold of hearing was higher in left ears but it mainly involved $3000 \mathrm{~Hz}$ and $8000 \mathrm{~Hz}$ frequencies.

\section{DISCUSSION}

The traffic police are continually exposed to loud noise. The increased traffic volume in Biratnagar showed that they might be exposed to noise induced hearing loss (NIHL). The studies done in different parts of Nepal have shown that the noise level in the many cities is more than the recommended level. ${ }^{3,4}$ So, the study was conducted among traffic Police of Biratnagar to screen the hearing ability and also to compare the normal threshold of hearing among traffic police and controls. Among 44, only 36 were selected for the study. In our result $22.2 \%$ (Table 1 ) showed tinnitus which is similar to the study done in Kathmandu valley ${ }^{4}$ but it is slightly less than the study done in Dharan- Biratnagar corridor $(33.33 \%) .{ }^{5}$ It may be because of difference in number of sample size. In our study only $22.2 \%$ (Table 1 ) of the traffic policemen showed ear fullness which is slightly less than the study done among traffic police in Kathmandu valley. ${ }^{4}$ Only $5.6 \%$ (Table 1) of them used protective measures which is similar to study done in Biratnagar- Dharan corridor. Duration of working hours is $8-10 \mathrm{hrs}$ in $66 \%$ of traffic policemen.On pure tone audiometric screening, 17 $(47.2 \%)$ showed hearing loss (Table 2$)$. It is less than the study done in Kathmandu valley which showed 66.4\%. It might have differed because of the difference in the number of sample size and the area where it was conducted. But the result in our was similar to the study conducted in Colombo Srilanka. ${ }^{9}$ Studies have also shown that $4 \mathrm{KHz}$ is mainly affected however neighboring frequencies are also affected. ${ }^{7,10,11}$ Similarly studies have suggested, though noise induced hearing loss (NIHL) is typically bilateral it can also be unilateral. ${ }^{7}$ In our study also, 8 (22.22\%) had involvement in $4 \mathrm{KHz}$ where the percentage of unilateral or bilateral hearing loss was same $4(11.11 \%)$ unilateral and $4(11.11 \%)$ however in $3 \mathrm{~Hz}$ frequency loss, unilateral loss was more (Table 3). Though the exact physiology behind the asymmetric hearing is not clear, left ears are shown to be affected more. However some have reported hearing loss in right ears also. ${ }^{11}$ In our study left ear was affected more compared to right ear (Table 4) which is similar to the studies done in Kathmandu city ${ }^{4}$ but it is different from another study which showed involvement of right ears compared to left ears. ${ }^{12}$ In our study, all those subjects having NIHL were referred to ENT OPD for further consultation. Out of 19 traffic police with normal hearing, only 11 could come for threshold measurement. Same numbers of age, sex and BMI matched controls were taken (Table 5) while 


\begin{tabular}{|c|c|c|c|c|c|c|}
\hline $\begin{array}{l}\text { Frequency } \\
(\mathrm{Hz})\end{array}$ & $\begin{array}{l}\text { Threshold traffic } \\
\text { police (right ear) } \\
\text { Mean } \pm S D n=11\end{array}$ & $\begin{array}{c}\text { Threshold } \\
\text { control (right ear) } \\
\text { Meann } \pm S D n=11\end{array}$ & p-value & $\begin{array}{l}\text { Threshold traffic } \\
\text { police (left ear) } \\
\text { Mean } \pm S D \text { n=11 }\end{array}$ & $\begin{array}{c}\text { Threshold } \\
\text { control (left ear) } \\
\text { Mean } \pm \text { SD } n=11\end{array}$ & $p$-value \\
\hline 250 & $11.82 \pm 5.60$ & $13.64 \pm 3.93$ & 0.390 & $20.45 \pm 6.50$ & $15.45 \pm 7.89$ & 0.121 \\
\hline 500 & $15.91 \pm 5.39$ & $16.36 \pm 3.23$ & 0.814 & $20.91 \pm 5.83$ & $15.45 \pm 6.50$ & 0.052 \\
\hline 1000 & $15.91 \pm 7.68$ & $12.73 \pm 4.67$ & 0.257 & $19.55 \pm 6.10$ & $15.45 \pm 5.68$ & 0.119 \\
\hline 2000 & $18.64 \pm 5.95$ & $16.82 \pm 3.37$ & 0.3 & $20.91 \pm 5.39$ & $18.18 \pm 4.62$ & 0.218 \\
\hline 3000 & $20.45 \pm 5.22$ & $15.91 \pm 4.90$ & 0.04 & $23.64 \pm 7.77$ & $19.55 \pm 4.71$ & 0.155 \\
\hline 4000 & $25.45 \pm 12.54$ & $16.82 \pm 5.60$ & 0.05 & $25.91 \pm 6.64$ & $20.45 \pm 4.15$ & 0.034 \\
\hline 8000 & $18.64 \pm 17.62$ & $6.36 \pm 3.23$ & 0.04 & $17.27 \pm 9.31$ & $11.82 \pm 7.83$ & 0.153 \\
\hline
\end{tabular}

\begin{tabular}{|c|c|c|c|c|c|c|}
\hline $\begin{array}{l}\text { Frequency } \\
(\mathrm{Hz})\end{array}$ & $\begin{array}{l}\text { Threshold traffic } \\
\text { police (right ear) } \\
\text { Mean } \pm S D n=11\end{array}$ & $\begin{array}{l}\text { Threshold traffic } \\
\text { police (left ear) } \\
\text { Mean } \pm S D \text { n=11 }\end{array}$ & p-value & $\begin{array}{c}\text { Threshold } \\
\text { control (right ear) } \\
\text { Mean } \pm S D n=11\end{array}$ & $\begin{array}{c}\text { Threshold } \\
\text { control (left ear) } \\
\text { Mean } \pm S D \text { n=11 }\end{array}$ & p-value \\
\hline 250 & $11.82 \pm 5.60$ & $20.45 \pm 6.50$ & 0.000 & $13.64 \pm 3.93$ & $15.45 \pm 7.89$ & 0.397 \\
\hline 500 & $15.91 \pm 5.39$ & $20.91 \pm 5.83$ & 0.000 & $16.36 \pm 3.23$ & $15.45 \pm 6.50$ & 0.588 \\
\hline 1000 & $15.91 \pm 7.68$ & $19.55 \pm 6.10$ & 0.070 & $12.73 \pm 4.67$ & $15.45 \pm 5.68$ & 0.167 \\
\hline 2000 & $18.64 \pm 5.95$ & $20.91 \pm 5.39$ & 0.016 & $16.82 \pm 3.37$ & $18.18 \pm 4.62$ & 0.192 \\
\hline 3000 & $20.45 \pm 5.22$ & $23.64 \pm 7.77$ & 0.111 & $15.91 \pm 4.90$ & $19.55 \pm 4.71$ & 0.038 \\
\hline 4000 & $25.45 \pm 12.54$ & $25.91 \pm 6.64$ & 0.902 & $16.82 \pm 5.60$ & $20.45 \pm 4.15$ & 0.070 \\
\hline 8000 & $18.64 \pm 17.62$ & $17.27 \pm 9.31$ & 0.781 & $6.36 \pm 3.23$ & $11.82 \pm 7.83$ & 0.014 \\
\hline
\end{tabular}

comparing normal threshold between traffic police and control, in the left ear traffic police had higher threshold of hearing only in $4 \mathrm{kHz}$ compared to controls $(\mathrm{p}=.034)$ (Table 6) but when compared in right ears, traffic policemen have higher threshold for hearing in $3000 \mathrm{~Hz}(p=0.04), 4000 \mathrm{~Hz}$ $(p=0.05)$ and $8000 \mathrm{~Hz}(p=0.04)$. This has some similarity with the study which has shown that the traffic policemen have higher thresholds in $2000 \mathrm{~Hz}, 4000 \mathrm{~Hz}$ and $8000 \mathrm{~Hz}$ in both right and left ears. ${ }^{13}$ But in our study the difference was mainly seen in right ears. This might be becausein our study we had selected only those subjects with normal hearing level. Since the percentage of hearing loss was more in left ears, we also compared the hearing threshold between left and right ears in each groups separately (Table 7), which showed traffic policemen had higher hearing threshold in left ears in frequencies of $250 \mathrm{~Hz}, 500 \mathrm{~Hz}$ and $3000 \mathrm{~Hz}$ which was also seen among controls but in frequencies of 3000 and $8000 \mathrm{~Hz}$.It is quite supportive to the studies which showed higher threshold of hearing in left ears compared to right ears in frequency between $3-6 \mathrm{KHz} .{ }^{14}$ But the differences in other frequencies needs further study.

\section{CONCLUSION}

Noise induced hearing loss was seen among traffic policemen. When the threshold of hearing was compared between traffic policemen and controls with hearing ability at $25 \mathrm{~dB}$, the threshold of hearing was higher among traffic police compared to controls. The left ears had higher threshold for hearing compared to right in both traffic police and controls. The observation suggests that proper system should be implemented to control further loss of hearing ability.

\section{Limitation}

The Limitation of the present study was the small sample size of subjects. So the statistical significance of the results should be interpreted with caution and also we could not quantify the noise level at different junctions. It is necessary to extend and the same observation in large scale.

\section{ACKNOWLEDGEMENT}

We express our sincere thanks to traffic police office Biratnagar and all the participants of the study. We are also very thankful to Nobel Medical college for support. We express our gratitude to Mr. Dilli Ram Niraula for support. We also express our sincere thanks to our lab technician Mr. Manoj Rajbansi for technical help.

\section{REFERENCES}

1. Nelson DI, Nelson RY, Concha-Barrientos $M$ and Fingerhut $\mathrm{M}$. The global burden of occupational noise-induced hearing loss. Am J Ind Med 2005; 48(6):446-458.

2. Kirchner DB, Evenson E, Dobie RA, et al. Occupational noise-induced hearing loss: ACOEM Task Force on Occupational Hearing Loss. J Occup Environ Med. 2012;54:106-108. doi: 10.1097/JOM.0b013e318242677d.

3. Rayamajhi KB. Assessment of Noise Pollution in Different Hatbazars of Butwal City, Rupandehi, Nepal. The Himalayan Physics 2017; 6: 61-64.

4. Shrestha I, Shrestha BL, Pokharel M, Amatya RC and Karki DR. Prevalence of noise induced hearing loss among traffic police 
personnel of Kathmandu Metropolitan City. Kathmandu Univ Med J (KUMJ) 2011; 9(36):274-283.

5. Ghimire A, Niraula, S, Shrestha A and Jha, N. Self-assessment of hearing quality of traffic policemen working in Dharan-Biratnagar corridor. Journal of Chitwan Medical College 2017;5(4): 20-26.

6. Bauer K, Cook D, Guillory L, Herndon D and Park K. Guidelines for hearing screening in the school setting [Internet]. Accessed on 18.07. 2019 11:55 pm. Available from: http://https://health.mo.gov/living/families/schoolhealth/pdf/ HearingScreeningGuidelines.pdf

7. Rabinowitz PM. Noise-induced hearing loss. Am Fam Physician 2000;61(9):2749-2756.

8. Kim SH, Won YS, Kim MG, Baek YJ, Oh IH and Yeo SG Relationship between obesity and hearing loss. Acta Otolaryngol 2016; 136(10):1046-1050.

9. Nagodawithana NS, Pathmeswaran A, Pannila AS Wickramasinghe AR and Sathiakumar N. Noise-induced Hearing Loss among Traffic Policemen in the City of Colombo, Sri Lanka. Asian Journal of Water, Environment and Pollution
2015; 12(3):9-14.

10. Rabinowitz PM, Galusha D, Slade MD, Dixon-Ernst C, Sircar KD and Dobie RA. Audiogram notches in noise-exposed workers. Ear Hear 2006; 27:742-750.

11. Le TN, Straatman LV, Lea J and Westerberg B. Current insights in noise-induced hearing loss: A literature review ofthe underlying mechanism, pathophysiology, asymmetry, and management options. J Otolaryngol Head Neck Surg 2017;46(1):41.

12. Nair $S$ and Kashyap RC. Prevalence of Noise Induced Hearing Loss in Indian Air Force Personnel. Med J Armed Forces India 2009; 65(3): 247-251.

13. Shelke B, Naundhkar VG, Adgaonkar BD, Somwanshi SD, Gavkare AM and Ghuge SH. A study on hearing threshold profile in traffic police personnel. IJMRHS 2013;2.

14. Pirila $\mathrm{T}$, Jounio-Ervasti $\mathrm{K}$ and Sorri $\mathrm{M}$. Left-right asymmetries in hearing threshold levels in three age groups of a random population. Audiology 1992;31(3):150-161.

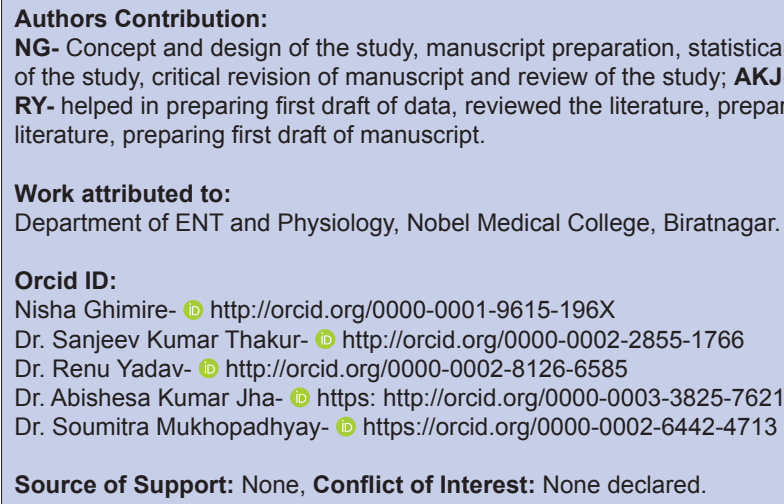




\section{APPENDIX}

Questionnaire for screening of traffic policemen

S.N -

Name

Age

Sex

Height

Weight

BMI

History

Duration of service-

Working hour in a single day-

previous job-

Do you listen to loud music-?

$\mathrm{H} / \mathrm{O}$ Diabetes Mellitus, Hypertension or any other disorders -

$\mathrm{H} / \mathrm{O}$ any ear infection-

$\mathrm{H} / \mathrm{O}$ Tinnitus-

$\mathrm{H} / \mathrm{O}$ ear-fullness-

$\mathrm{H} / \mathrm{O}$ of neck or head injury-

General examination

$\begin{array}{ll}\text { Pulse } & \text { Icterus } \\ \text { Cyanosis } & \text { Clubbing } \\ \text { Lymphnode } & \text { edema }\end{array}$

Blood pressure

Systemic examination

Ear findings

Pure tone audiometric examination 